\title{
A Loop-Mediated Isothermal Amplification Assay for Rapid Detection of Cyprinid Herpesvirus 2 in Gibel Carp (Carassius auratus gibelio)
}

\author{
Hui Zhang, Lingbing Zeng, Yuding Fan, Yong Zhou, Jin Xu, and Jie Ma \\ Division of Fish Disease, Yangtze River Fisheries Research Institute, Chinese Academy of Fishery Sciences, Wuhan, \\ Hubei 430223, China
}

Correspondence should be addressed to Lingbing Zeng; zenglingbing@gmail.com

Received 17 August 2013; Accepted 28 October 2013; Published 19 January 2014

Academic Editors: M. Chang and K. Kapiris

Copyright (C) 2014 Hui Zhang et al. This is an open access article distributed under the Creative Commons Attribution License, which permits unrestricted use, distribution, and reproduction in any medium, provided the original work is properly cited.

A rapid and sensitive loop-mediated isothermal amplification (LAMP) assay for Cyprinid herpesvirus 2 (CyHV-2) detection in gibel carp was developed. Following cloning and sequencing of the putative DNA helicase gene of CyHV-2 isolate from China, a set of four specific primers was designed based on the sequence. The $\mathrm{MgCl}_{2}$ concentration and the reaction temperature were optimized to $6 \mathrm{mM}, 64^{\circ} \mathrm{C}$, respectively. LAMP products were detected by visual inspection of a color change due to addition of SYBR Green I stain. The specificity and sensitivity of the LAMP assay were determined. No cross-reaction was observed with other fish DNA viruses including eel herpesvirus, koi herpesvirus, and Chinese giant salamander iridovirus. The LAMP assay was found to be equally sensitive as nested PCR. A comparative evaluation of 10 fish samples using LAMP and nested PCR assays showed an overall correlation in positive and negative results for CyHV-2. These results indicate that the LAMP assay is simple, sensitive, and specific and has a great potential use for CyHV-2 detection in the laboratory and field.

\section{Introduction}

Herpesviral hematopoietic necrosis (HVHN), caused by Cyprinid herpesvirus 2 (CyHV-2), is a disease of goldfish Carassius auratus auratus (Linnaeus, 1758) that was first reported in juvenile goldfish in Japan in the spring and autumn of 1992 and the spring of 1993 and later in Australia, Taiwan, and the USA $[1,2]$. The CyHV-2 has been classified as a member of the genus Cyprinivirus, the family Alloherpesviridae in the Herpesvirales order, and its complete genome has been sequenced (GenBank accession JQ815364).

Molecular tools such as polymerase chain reaction (PCR) and quantitative real-time PCR have been established for the detection and quantification of CyHV-2 [1-7]. However, these methods require the use of expensive equipment and costly consumables, which have limited their application. Loop-mediated isothermal amplification (LAMP) is a technique that has been developed to amplify nucleic acids with high specificity, sensitivity, and rapidity under isothermal conditions [8]. In aquaculture, LAMP assays have been developed to detect fish and shellfish pathogens including aquatic DNA viruses such as red seabream iridovirus (RSIV) [9], white spot syndrome virus (WSSV) [10-14], koi herpesvirus (KHV, CyHV-3) [15-19], infectious hypodermal and hematopoietic necrosis virus (IHHNV) [20-22], hepatopancreatic parvovirus (PmDNV) [23], Singapore grouper iridovirus (SGIV) [24], acute viral necrobiotic virus (AVNV) [25], turbot reddish body iridovirus (TRBIV) [26], infectious spleen and kidney necrosis virus (ISKNV) [27], lymphocystis disease virus (LCDV) [28], ostreid herpesvirus 1 (OsHV-1) [29], and soft shelled turtle iridovirus (STIV) [30]. Therefore, LAMP has been a useful tool for the diagnosis of aquatic animal diseases.

Gibel carp (Carassius auratus gibelio) is a major species of aquaculture in China, which has been widely cultured in almost the whole country. Recently, an epizootic with severe mortality has emerged in cultured gibel carp in China 
TABLE 1: Primer names and sequences used in the study.

\begin{tabular}{lcc}
\hline Primer & Sequence $\left(5^{\prime} \rightarrow 3^{\prime}\right)$ & Position \\
\hline JF & ATGTGCAACGTGACGGCGAGT & $1-21$ \\
JR & CTACCGTCTTTTAGGG & $1446-1431$ \\
JF1 & TGAAATGTCAAAAGTGGATGG & $239-259$ \\
JR1 & TATTCCCAGACAGCCTTCAAA & $954-934$ \\
JF2 & GAACACCGCTGCTCATCATC & $323-342$ \\
JR2 & ACTCTTCGCAAGTCCTCACC \\
JF3 & TTGGATCTGAACGCTTCGG & $679-660$ \\
JB3 & CGTTGGTCTGTATGGGAGC & $97-115$ \\
JFIP & GCGATGTAAGCCCTGTGAGACTTTTTACGAGACGTGGTTCCTAGC & $286-304$ \\
JBIP & AACGCACGAGTGCGAGTCTCTTTTGCTGTGGATCGTCCATCC & $176-197 / T T T T / 116-134$ \\
& & $204-223 / T T T T / 254-271$ \\
\hline
\end{tabular}

GenBank accession number KC245087
F3
81CAACACGACCGAGCTG TTGGATCTGAACGCTTCGGACGAGACGTGGTTCCTAGCCTACAA
GTTGTGCTGGCTCGACAACCTAGACTTGCGAAGCCTGCTCTGCACCAAGGATCGGATGTT
141GGAGAGACACAAGGAGTCCCTGAATAATCTACAAAAGTCTCACAGGGCTTACATCGCCAA
CCTCTCTGTGTTCCTCAGGGACTTATTAGATGTTTCAGAGTGTCCCGAATGTAGCGGTT
B1c
201CCCAACGCACGAGTGCGAGTCTCTCAGGATGAGATGCATGAAATGTCAAAAGTGGATGGA
GGGTTGCGTGCTCACGCTCAGAGAGTCCTACTCTACGTACTTTACAGTTTTCACCTACCT
261CGATCCACAGCTACCCAATAACGCCGCTCCCATACAGACCAACGTGTTTTCGGGTCCCGC
$\frac{\text { GCTAGGTGTCGATGGGTTATTGCGGCGAGGGTATGTCTGGTTGCACAAAAGCCCAGGGCG }}{\text { B2 }}$

FIgURE 1: The nucleotide sequence of partial CyHV-2 DNA helicase gene used to design inner and outer primers for LAMP.

and caused huge economic loss. The causative pathogen was isolated and identified as Cyprinid herpesvirus 2 (CyHV-2) by means of experimental infection, electron microscopy, cell culture, PCR assay, and sequence alignment [31]. In this study, a highly sensitive and specific diagnostic method based on the loop-mediated isothermal amplification (LAMP) for CyHV-2 detection in gibel carp was developed following cloning and sequencing of the DNA helicase gene of CyHV-2. Meanwhile, the reaction conditions were optimized and the specificity and sensitivity of the LAMP assay were assessed. This study represents the first report of LAMP assay for CyHV-2 detection in cultured gibel carp, which has great potential use in both laboratory and field diagnosis of the disease.

\section{Materials and Methods}

2.1. Viruses, Fish Samples, and Preparation of DNA Template. Cyprinid herpesvirus 2 (CyHV-2), eel herpesvirus (AngHV1), koi herpes virus (KHV, CyHV-3), and Chinese giant salamander iridovirus (GSIV) were isolated and kept in our laboratory.

Diseased gibel carp $(15-28 \mathrm{~cm}$ in length) were obtained from the farms in Jiangsu province, China in May 2012. Healthy fish were obtained from the experimental station,
Yangtze River Fisheries Research Institute, Chinese Academy of Fishery Sciences.

The spleen and kidney of the diseased gibel carp with severe hemorrhagic symptoms were collected and homogenized on ice in DPBS (Sigma, USA) at a ratio of 1:5 w/v. After being frozen-thawed twice, the homogenate was centrifuged at $4,500 \times \mathrm{g}$ for $30 \mathrm{~min}$ at $4^{\circ} \mathrm{C}$ (Sigma $3 \mathrm{~K} 15$ ). $250 \mu \mathrm{L}$ of supernatant was used for DNA extraction with a commercial kit (Viral DNA Kit, OMEGA, USA) according to the manufacturer's protocol. The final elution of viral DNA was in $100 \mu \mathrm{L}$ sterile $\mathrm{ddH}_{2} \mathrm{O}$ and stored at $-20^{\circ} \mathrm{C}$ for use.

2.2. Primers Design. A PCR primer set (JF/JR) was designed to amplify the complete cds of the viral putative DNA helicase gene (GenBank accession EU349287). Then nested PCR primers (JF1/JR1, JF2/JR2) were designed for detection (GenBank accession KC245087) by software Primer Premier 5.0 .

A set of four LAMP primers (JF3 and JB3, JBIP and JFIP) recognizing six distinct regions in the viral putative DNA helicase gene sequence (GenBank accession KC245087) was designed by using the Primer Explorer version 4 (http://primerexplorer.jp/elamp4.0.0/index.html). The primers' sequences and the locations were indicated in Figure 1. All primers were synthesized (Invitrogen, Shanghai, China) and are shown in Table 1. 
2.3. Cloning and Sequencing of the Putative DNA Helicase Gene of $C y H V$-2. The putative DNA helicase gene of CyHV2 was amplified by PCR. The reaction mixture contained $0.2 \mu \mathrm{M}$ each of JF and JR, $0.2 \mathrm{mM}$ of dNTP mix, $1 \times$ PCR buffer, $2.5 \mathrm{U}$ of Taq DNA polymerase (Takara, Dalian, China), $5 \mu \mathrm{L}$ DNA template in a final volume adjusted to $25 \mu \mathrm{L}$ with sterile $\mathrm{ddH}_{2} \mathrm{O}$. The PCR thermal cycling protocol was $5 \mathrm{~min}$ at $95^{\circ} \mathrm{C}$ followed by 30 cycles of $95^{\circ} \mathrm{C}$ for $45 \mathrm{~s}, 56^{\circ} \mathrm{C}$ for $45 \mathrm{~s}, 72^{\circ} \mathrm{C}$ for $60 \mathrm{~s}$, and a final extension at $72^{\circ} \mathrm{C}$ for $10 \mathrm{~min}$ ending in $4^{\circ} \mathrm{C}$ hold. PCR product was purified and cloned into the pMD18-T Vector (Takara, Dalian, China) according to the manufacturer's protocol; the recombinant plasmid was sequenced (Sangon, Shanghai, China).

2.4. Nested PCR Detection. Nested PCR was carried out using the primers designed. The first PCR was carried out with an outer primer set (JF1 and JR1), yielding a PCR product with $716 \mathrm{bp}$. The nested PCR was performed with an inner primer set (JF2 and JR2), yielding a PCR product with $357 \mathrm{bp}$.

The PCR reactions contained $0.2 \mu \mathrm{M}$ each of primers, $0.2 \mathrm{mM}$ of dNTP mix, $1 \times$ PCR buffer, $2.5 \mathrm{U}$ of Taq DNA polymerase (Sangon, Shanghai, China), $5 \mu \mathrm{L}$ DNA template, and sterile $\mathrm{ddH}_{2} \mathrm{O}$ in a final volume of $25 \mu \mathrm{L}$. Amplification conditions were as follows: $95^{\circ} \mathrm{C}$ for $3 \mathrm{~min}$, then 35 cycles of denaturation at $95^{\circ} \mathrm{C}$ for $30 \mathrm{~s}$, annealing at $55^{\circ} \mathrm{C}$ for $30 \mathrm{~s}$, extension at $72^{\circ} \mathrm{C}$ for $50 \mathrm{~s}$, followed by a final elongation at $72^{\circ} \mathrm{C}$ for $5 \mathrm{~min}$.

$0.5 \mu \mathrm{L}$ of the first PCR product was used as DNA template for the nested PCR amplification using the same conditions as stated above. PCR products were electrophoresed on a $2 \%(\mathrm{w} / \mathrm{v})$ ethidium bromide-stained agarose gel in Tris-boric acid-EDTA (TBE) buffer.

2.5. Optimization of LAMP Reaction Conditions. To optimize the LAMP reaction, different reaction temperatures and $\mathrm{MgCl}_{2}$ concentrations were tested. The LAMP reactions were performed using a heating block set at $60,61,62,63$, 64 , and $65^{\circ} \mathrm{C}$ for $60 \mathrm{~min}$, respectively. The LAMP reactions were incubated in a heating block set at $64^{\circ} \mathrm{C}$ for $60 \mathrm{~min}$, containing $0,2,4,6,8$, and $10 \mathrm{mM} \mathrm{MgCl}_{2}$, respectively.

The reaction mixture $(25 \mu \mathrm{L})$ contained $1.6 \mu \mathrm{M}$ each of inner primer (JBIP and JFIP), $0.2 \mu \mathrm{M}$ each of outer primer (JF3 and JB3), $1 \mathrm{mM}$ of dNTP mix, $0.5 \mathrm{M}$ betaine (Sigma, USA), $6 \mathrm{mM} \mathrm{MgCl}_{2}, 8 \mathrm{U}$ Bst DNA polymerase large fragment (New England Biolabs, USA), $1 \times$ the supplied buffer, and $5 \mu \mathrm{L}$ template DNA that was heated at $95^{\circ} \mathrm{C}$ for $5 \mathrm{~min}$. Sterile $\mathrm{ddH}_{2} \mathrm{O}$ was included as negative control. The products were analyzed by $2 \%$ agarose gel electrophoresis.

2.6. Detection of LAMP Products. After LAMP reaction, white turbidity of the reaction mixture by magnesium pyrophosphate (by-product of LAMP) was inspected. Visual inspection of LAMP amplification was carried out by mixing $4 \mu \mathrm{L}$ products with $6 \mu \mathrm{L} 100$-fold diluted original SYBR Green I (Molecular Probes, Inc.). The color change in the tubes was examined under natural light with the naked eye. Green fluorescence was observed clearly in the positive reaction, whereas it remained original orange in the negative reaction. The mixture was also examined under UV light $(302 \mathrm{~nm})$. Reaction products were also analysed by gel electrophoresis, $5 \mu \mathrm{L}$ aliquots were analysed on a $2 \%$ agarose gel with ethidium bromide.

2.7. Specificity of the LAMP Assay. The specificity of the LAMP assay to amplify only CyHV-2 DNA was tested against DNA extracted from other viruses including eel herpesvirus (AngHV-1), koi herpesvirus (KHV, CyHV-3), and Chinese giant salamander iridovirus (GSIV). Sterile $\mathrm{dd}_{2} \mathrm{O}$ was used as a negative control. The LAMP products were analyzed by $2 \%$ agarose gel electrophoresis.

2.8. Sensitivity of the LAMP Assay. To determine the lower detection limit of the LAMP assay, $5 \mu \mathrm{L}$ of CyHV-2 DNA extracted from diseased fish was 10 -fold serially diluted and subjected to CyHV-2 LAMP assay in comparison with nested PCR assay. The LAMP reaction was performed at $64^{\circ} \mathrm{C}$ for 60 min. Nested PCR was also performed for the same samples simultaneously. Amplification products were analyzed by agarose gel electrophoresis.

2.9. Evaluation of the LAMP Assay. The use of CyHV-2 LAMP assay to detect CyHV-2 in clinical specimens was evaluated by testing a total of 5 CyHV-2 infected and 5 healthy fish, which were tested previously by nested PCR. Amplification products were analyzed by agarose gel electrophoresis.

\section{Results}

3.1. Analysis of the Putative DNA Helicase Gene of CyHV2. Analysis of the viral DNA helicase gene obtained in this study showed that it was almost identical with that of the Japanese strain of CyHV-2. When the sequence alignment (BLAST) was performed, 99\% nucleotide identity to the published CyHV-2 sequences (GenBank accession JQ815364, EU349287) was observed. However, these differences resulted in no alteration of the amino acid sequence (GenBank accession JQ815364), but only one amino acid alteration (GenBank accession EU349287). The sequence of the DNA helicase gene of CyHV-2 isolated from gibel carp in this study was deposited in GenBank (accession number KC245087).

3.2. Optimization of the LAMP Reaction Conditions. The optimal LAMP reaction temperature revealed that although detectable results were observed at $62-65^{\circ} \mathrm{C}$, the LAMP product amplified at $64^{\circ} \mathrm{C}$ exhibited slightly larger amounts of DNA as compared to others (Figure 2(a)).

The optimal $\mathrm{MgCl}_{2}$ concentration for LAMP showed that tests with 2-8 $\mathrm{mM} \mathrm{MgCl}_{2}$ gave detectable results but that the clearest bands were obtained with $6 \mathrm{mM} \mathrm{MgCl}_{2}$ (Figure 2(b)).

Thus, the optimal reaction conditions were $6 \mathrm{mM} \mathrm{MgCl}_{2}$, $64^{\circ} \mathrm{C}$. In addition, because loop primers were not used, 60 min was chosen arbitrarily as the assay time, consistent with the classic report about LAMP [8]. These conditions were used in the subsequent experiments. 


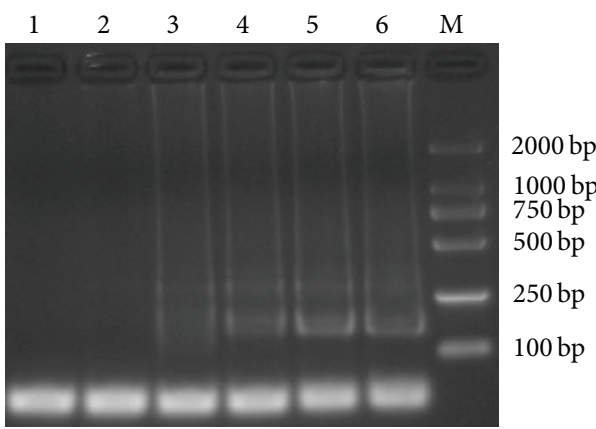

(a)

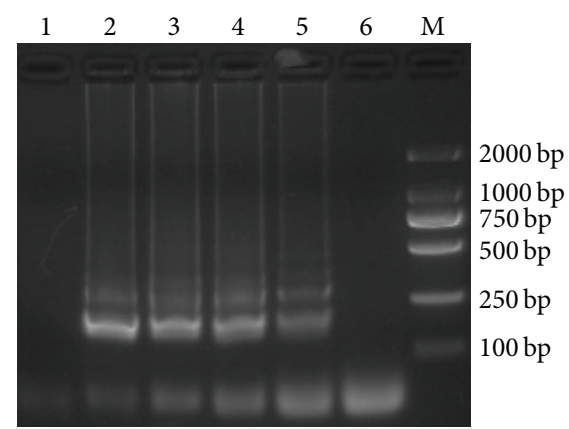

(b)

Figure 2: Optimization of the LAMP reaction conditions. (a) Reaction temperature: $1-6: 60^{\circ} \mathrm{C}, 61^{\circ} \mathrm{C}, 62^{\circ} \mathrm{C}, 63^{\circ} \mathrm{C}, 64^{\circ} \mathrm{C}$, and $65^{\circ} \mathrm{C}$, M: DL2000 DNA marker. (b) $\mathrm{MgCl}_{2}$ concentration: 1-6: $0 \mathrm{mM}, 2 \mathrm{mM}, 4 \mathrm{mM}, 6 \mathrm{mM}, 8 \mathrm{mM}$, and $10 \mathrm{mM} \mathrm{MgCl}_{2}$ : M: DL2000 DNA marker.

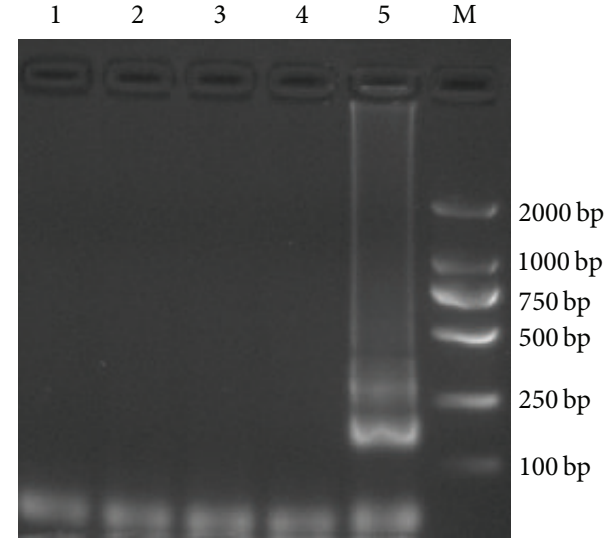

FIGURE 3: Specificity of the LAMP assay. 1: negative control; 2: GSIV; 3: AngHV-1; 4: KHV; 5: CyHV-2; M: DL2000 DNA marker.

3.3. Specificity of the LAMP Assay. The LAMP assay result showed that a typical ladder-like pattern was observed only when the CyHV-2 DNA was present. There were no amplification products detected with eel herpesvirus (AngHV-1), koi herpesvirus (KHV, CyHV-3), or Chinese giant salamander iridovirus (GSIV) genomic DNA (Figure 3).

3.4. Sensitivity of the LAMP Assay. The reaction was tested using $5 \mu \mathrm{L}$ of the 10 -fold serial dilutions of CyHV-2 DNA extracted from positive clinical samples and compared against results from the nested PCR assay. When LAMP reactions were carried out at $64^{\circ} \mathrm{C}$ for $60 \mathrm{~min}$, the LAMP could result in amplification of up to $10^{-3}$ dilution, comparable to nested PCR (Figures 4 and 5). These observations also showed that the results of the LAMP assay determined by the naked eye or by UV spectroscopy agreed with those obtained by gel electrophoresis.

3.5. Applicability of the LAMP Assay. When fish samples were tested, the LAMP assay results correlated strongly with nested PCR results for CyHV-2 detection (data not shown). The positive samples tested by nested PCR also gave positive

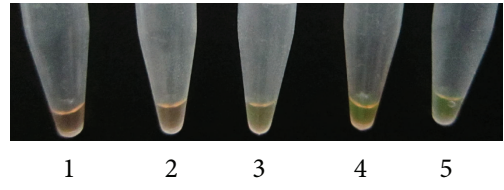

(a)

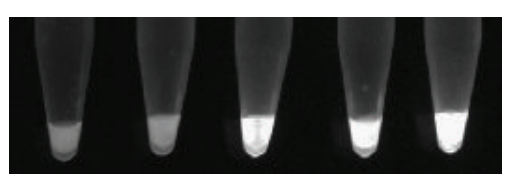

(b)

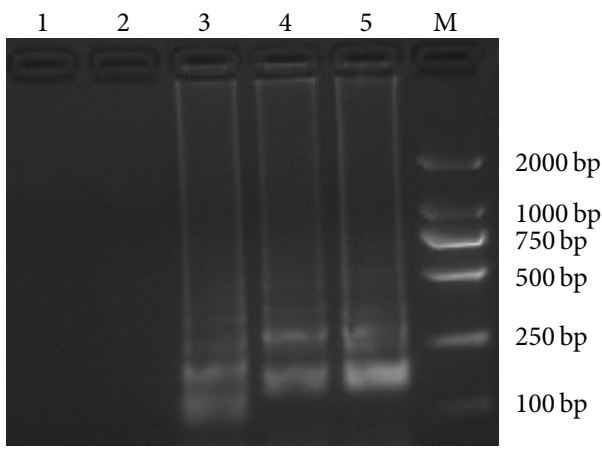

(c)

FIGURE 4: Sensitivity of the LAMP assay. Visual inspection in daylight (a), under UV light (b), and with $2 \%$ agarose gel electrophoresis (c). 1: negative control; $2: 10^{-4}$ dilution; $3: 10^{-3}$ dilution; $4: 10^{-2}$ dilution; 5: $10^{-1}$ dilution; M: DL2000 DNA marker.

reactions with LAMP, and no sample that was negative by nested PCR tested positive with the LAMP assay, which proved the applicability of the assay in CyHV-2 disease diagnosis.

\section{Discussion}

The most classic technique for detection of viral pathogens is virus isolation by cell culture, but this technique depends 


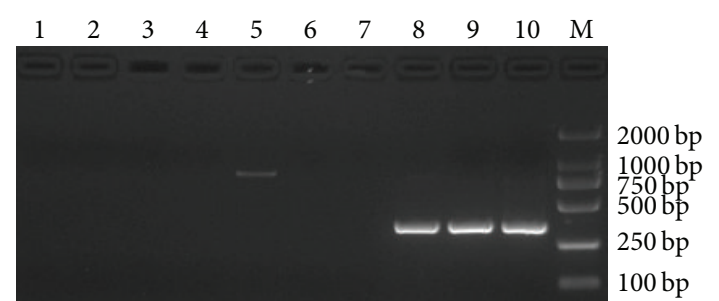

FIgURE 5: Sensitivity of the nested PCR assay. 1-5: the first PCR products; $6-10$ : the second PCR products. 1, 6: negative control; 2, 7: $10^{-4}$ dilution; $3,8: 10^{-3}$ dilution. $4,9: 10^{-2}$ dilution; 5, 10:10 $10^{-1}$ dilution; M: DL2000 DNA marker.

on the subculture of cells and virus and is time consuming. It is reported that the CyHV-2 is very difficult to be cultured in cells $[1-4,31]$, so the PCR and real-time PCR assays are mainly used for detection and quantification of CyHV-2 [17]. In this study, the LAMP assay for CyHV-2 detection was developed successfully.

The LAMP reaction conditions, including $\mathrm{MgCl}_{2}$ concentration and reaction temperature, were optimized first in the study. The optimal conditions of LAMP reaction for the detection were determined at $64^{\circ} \mathrm{C}$ for $60 \mathrm{~min}$ with $6 \mathrm{mM} \mathrm{MgCl}_{2}$.

Specificity and sensitivity are the most important parameters to evaluate an assay. LAMP assays carried out using DNA templates from AngHV-1, KHV (CyHV-3) and GSIV gave no positive results (i.e., no amplification). The results indicated that the LAMP assay was specific for CyHV-2. The detection limit of the LAMP assay was determined by amplification of 10 -fold serial dilutions. The results obtained by LAMP gave comparable sensitivity to those of nested PCR at $10^{-3}$ dilution, which was in agreement with previous reports [11, 22, 23].

Use of SYBR Green I for visual inspection of LAMP results was a simple and superior technique, with no gel electrophoresis and staining with ethidium bromide required. Positive and negative reactions showed distinctly different colors in daylight on a black background [26]. Although quantitative detection is difficult, the eye inspection was simple and rapid. Therefore, it may facilitate the application of LAMP, especially as a field test.

According to known sequences, the viral DNA helicase gene used as the target in the LAMP assay is relatively well conserved, which was useful for detection of all CyHV2 isolates. Our final goal is to exploit a simple and rapid diagnostic kit for diagnosis and monitoring of $\mathrm{CyHV}-2$ in fish farms, as it does not require special equipment. Further studies are considered, such as a simple DNA extraction method by tissue boiling.

In conclusion, a simple, rapid, and sensitive LAMP assay to detect CyHV-2 in fish was developed and validated. In this simple diagnostic protocol, the reaction was carried out in a single tube and incubated for $60 \mathrm{~min}$ in a water bath or a heating block at $64^{\circ} \mathrm{C}$. LAMP products could be detected by the naked eye with the aid of SYBR Green I stain, which could facilitate field implementation of the LAMP assay.

\section{Conflict of Interests}

The authors declare that there is no conflict of interests regarding the publication of this paper.

\section{Acknowledgments}

This study was supported by the Earmarked Fund for China Agriculture Research System (CARS-46-11), the Special Scientific Research Funds for Central Non-Profit Institutes, Chinese Academy of Fishery Sciences (2013A0606), and the Director Fund of Yangtze River Fisheries Research Institute (SZ2012-03).

\section{References}

[1] A. E. Goodwin, G. E. Merry, and J. Sadler, "Detection of the herpesviral hematopoietic necrosis disease agent (Cyprinid herpesvirus 2) in moribund and healthy goldfish: validation of a quantitative PCR diagnostic method," Diseases of Aquatic Organisms, vol. 69, no. 2-3, pp. 137-143, 2006.

[2] K. R. Jeffery, K. Bateman, A. Bayley et al., "Isolation of a cyprinid herpesvirus 2 from goldfish, Carassius auratus (L.), in the UK," Journal of Fish Diseases, vol. 30, no. 11, pp. 649-656, 2007.

[3] A. E. Goodwin, L. Khoo, S. E. Lapatra et al., "Goldfish hematopoietic necrosis herpesvirus (cyprinid herpesvirus 2) in the USA: molecular confirmation of isolates from diseased fish," Journal of Aquatic Animal Health, vol. 18, no. 1, pp. 11-18, 2006.

[4] A. E. Goodwin, J. Sadler, G. E. Merry, and E. N. Marecaux, "Herpesviral haematopoietic necrosis virus (CyHV-2) infection: case studies from commercial goldfish farms," Journal of Fish Diseases, vol. 32, no. 3, pp. 271-278, 2009.

[5] T. B. Waltzek, T. Kurobe, A. E. Goodwin, and R. P. Hedrick, "Development of a polymerase chain reaction assay to detect cyprinid herpesvirus 2 in goldfish," Journal of Aquatic Animal Health, vol. 21, no. 1, pp. 60-67, 2009.

[6] A. Doszpoly, M. Benko, G. Csaba, A. Dan, M. Lang, and B. Harrach, "Introduction of the family Alloherpesviridae: the first molecular detection of herpesviruses of cyprinid fish in Hungary," Magyar Allatorvosok Lapja, vol. 133, no. 3, pp. 174$181,2011$.

[7] Y. Zhou, L. Zeng, H. Zhang, Y. Fan, and J. Xu, "Establishment of a TaqMan real-time PCR assay for detecting the Cyprinid herpesvirus II," Journal of Fisheries of China, vol. 37, no. 4, pp. 607-613, 2013.

[8] T. Notomi, H. Okayama, H. Masubuchi et al., "Loop-mediated isothermal amplification of DNA," Nucleic Acids Research, vol. 28, no. 12, article e63, 2000.

[9] C. M. A. Caipang, I. Haraguchi, T. Ohira, I. Hirono, and T. Aoki, "Rapid detection of a fish iridovirus using loop-mediated isothermal amplification (LAMP)," Journal of Virological Methods, vol. 121, no. 2, pp. 155-161, 2004.

[10] T. Kono, R. Savan, M. Sakai, and T. Itami, "Detection of white spot syndrome virus in shrimp by loop-mediated isothermal amplification," Journal of Virological Methods, vol. 115, no. 1, pp. 59-65, 2004.

[11] W. Jaroenram, W. Kiatpathomchai, and T. W. Flegel, "Rapid and sensitive detection of white spot syndrome virus by loopmediated isothermal amplification combined with a lateral flow dipstick," Molecular and Cellular Probes, vol. 23, no. 2, pp. 65-70, 2009. 
[12] T. Mekata, R. Sudhakaran, T. Kono et al., "Real-time quantitative loop-mediated isothermal amplification as a simple method for detecting white spot syndrome virus," Letters in Applied Microbiology, vol. 48, no. 1, pp. 25-32, 2009.

[13] P.-H. Chou, Y.-C. Lin, P.-H. Teng, C.-L. Chen, and P.-Y. Lee, "Real-time target-specific detection of loop-mediated isothermal amplification for white spot syndrome virus using fluorescence energy transfer-based probes," Journal of Virological Methods, vol. 173, no. 1, pp. 67-74, 2011.

[14] Y. Seetang-Nun, W. Jaroenram, S. Sriurairatana, R. Suebsing, and W. Kiatpathomchai, "Visual detection of white spot syndrome virus using DNA-functionalized gold nanoparticles as probes combined with loop-mediated isothermal amplification," Molecular and Cellular Probes, vol. 27, no. 2, pp. 71-79, 2013.

[15] I. Gunimaladevi, T. Kono, M. N. Venugopal, and M. Sakai, "Detection of koi herpesvirus in common carp, Cyprinus carpio L., by loop-mediated isothermal amplification," Journal of Fish Diseases, vol. 27, no. 10, pp. 583-589, 2004.

[16] H. Soliman and M. El-Matbouli, "Loop mediated isothermal amplification combined with nucleic acid lateral flow strip for diagnosis of cyprinid herpes virus-3," Molecular and Cellular Probes, vol. 24, no. 1, pp. 38-43, 2010.

[17] H. Soliman and M. El-Matbouli, "Immunocapture and direct binding loop mediated isothermal amplification simplify molecular diagnosis of Cyprinid herpesvirus-3," Journal of Virological Methods, vol. 162, no. 1-2, pp. 91-95, 2009.

[18] H. Soliman and M. El-Matbouli, "An inexpensive and rapid diagnostic method of Koi Herpesvirus (KHV) infection by loop-mediated isothermal amplification," Virology Journal, vol. 2, article 83, 2005.

[19] M. Yoshino, H. Watari, T. Kojima, M. Ikedo, and J. Kurita, "Rapid, sensitive and simple detection method for koi herpesvirus using loop-mediated isothermal amplification," Microbiology and Immunology, vol. 53, no. 7, pp. 375-383, 2009.

[20] Z.-F. Sun, C.-Q. Hu, C.-H. Ren, and Q. Shen, "Sensitive and rapid detection of infectious hypodermal and hematopoietic necrosis virus (IHHNV) in shrimps by loop-mediated isothermal amplification," Journal of Virological Methods, vol. 131, no. 1, pp. 41-46, 2006.

[21] L. He, H.-S. Xu, M.-Z. Wang, and H.-N. Rong, "Development of rapid detection of infectious hypodermal and hematopoietic necrosis virus by loop-mediated isothermal amplification," Chinese Journal of Virology, vol. 26, no. 6, pp. 490-495, 2010.

[22] N. Arunrut, P. Prombun, V. Saksmerprome, T. W. Flegel, and W. Kiatpathomchai, "Rapid and sensitive detection of infectious hypodermal and hematopoietic necrosis virus by loopmediated isothermal amplification combined with a lateral flow dipstick," Journal of Virological Methods, vol. 171, no. 1, pp. 21-25, 2011.

[23] T. Nimitphak, W. Kiatpathomchai, and T. W. Flegel, "Shrimp hepatopancreatic parvovirus detection by combining loopmediated isothermal amplification with a lateral flow dipstick," Journal of Virological Methods, vol. 154, no. 1-2, pp. 56-60, 2008.

[24] X. L. Mao, S. Zhou, D. Xu, J. Gong, H. C. Cui, and Q. W. Qin, "Rapid and sensitive detection of Singapore grouper iridovirus by loop-mediated isothermal amplification," Journal of Applied Microbiology, vol. 105, no. 2, pp. 389-397, 2008.

[25] W. C. Ren, C. M. Wang, and Y. Y. Cai, "Loop-mediated isothermal amplification for rapid detection of acute viral necrobiotic virus in scallop Chlamys farreri," Acta Virologica, vol. 53, no. 3, pp. 161-167, 2009.
[26] Q. Zhang, C. Shi, J. Huang, K. Jia, X. Chen, and H. Liu, "Rapid diagnosis of turbot reddish body iridovirus in turbot using the loop-mediated isothermal amplification method," Journal of Virological Methods, vol. 158, no. 1-2, pp. 18-23, 2009.

[27] W. C. Ding, J. Chen, Y. H. Shi, X. J. Lu, and M. Y. Li, "Rapid and sensitive detection of infectious spleen and kidney necrosis virus by loop-mediated isothermal amplification combined with a lateral flow dipstick," Archives of Virology, vol. 155, no. 3, pp. 385-389, 2010.

[28] Q. Li, Z. Yue, H. Liu et al., "Development and evaluation of a loop-mediated isothermal amplification assay for rapid detection of lymphocystis disease virus," Journal of Virological Methods, vol. 163, no. 2, pp. 378-384, 2010.

[29] W. Ren, T. Renault, Y. Cai, and C. Wang, "Development of a loop-mediated isothermal amplification assay for rapid and sensitive detection of ostreid herpesvirus 1 DNA," Journal of Virological Methods, vol. 170, no. 1-2, pp. 30-36, 2010.

[30] Z. Liu, H. Liu, X. Xie, J. He, T. Luo, and Y. Teng, "Evaluation of a loop-mediated isothermal amplification assay for rapid diagnosis of soft-shelled turtle iridovirus," Journal of Virological Methods, vol. 173, no. 2, pp. 328-333, 2011.

[31] J. Xu, L. Zeng, H. Zhang, Y. Zhou, J. Ma, and Y. Fan, “Cyprinid herpesvirus 2 infection emerged in cultured gibel carp, Carassius auratus gibelio in China," Veterinary Microbiology, vol. 166, no. 3, pp. 138-144, 2013. 

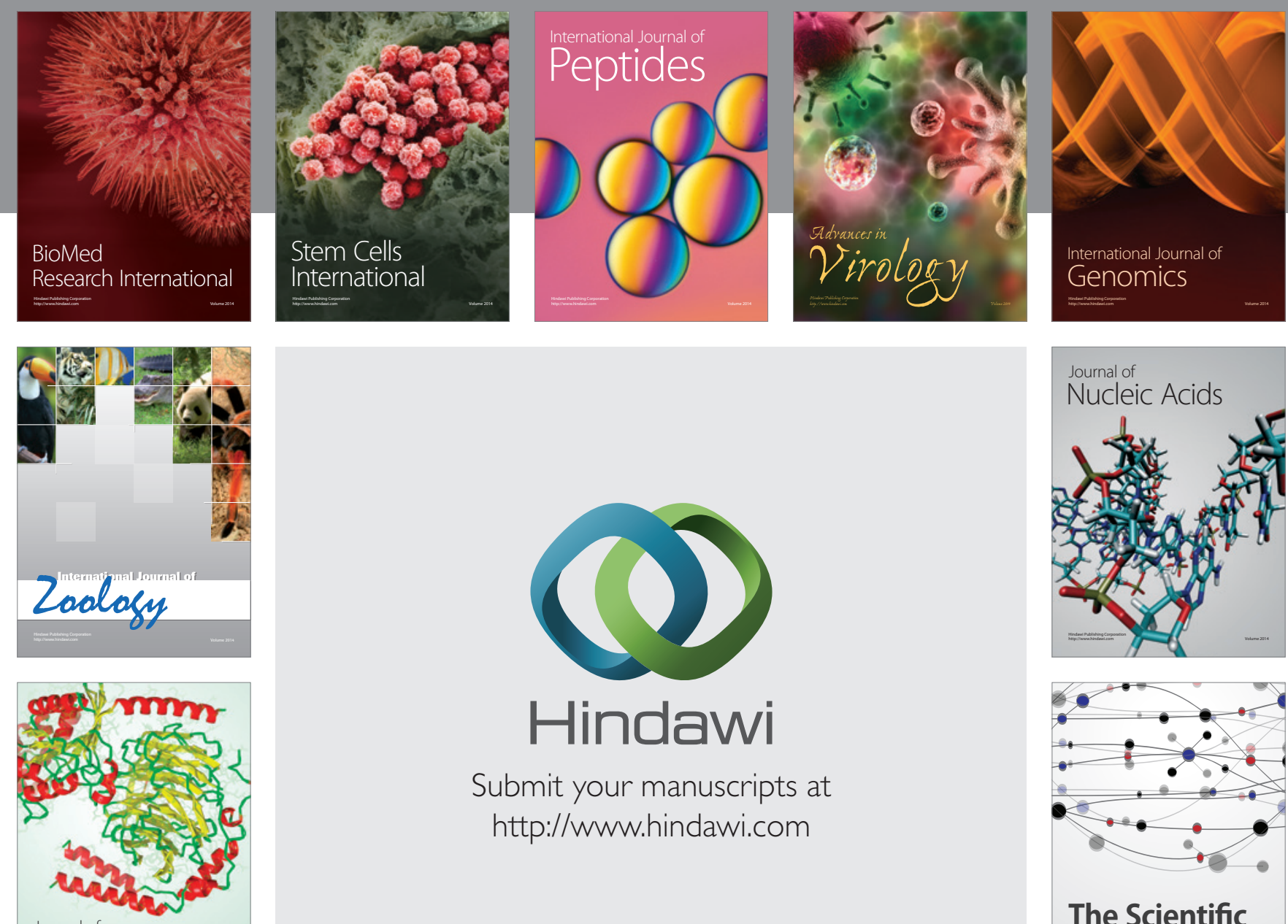

Submit your manuscripts at

http://www.hindawi.com

Journal of
Signal Transduction
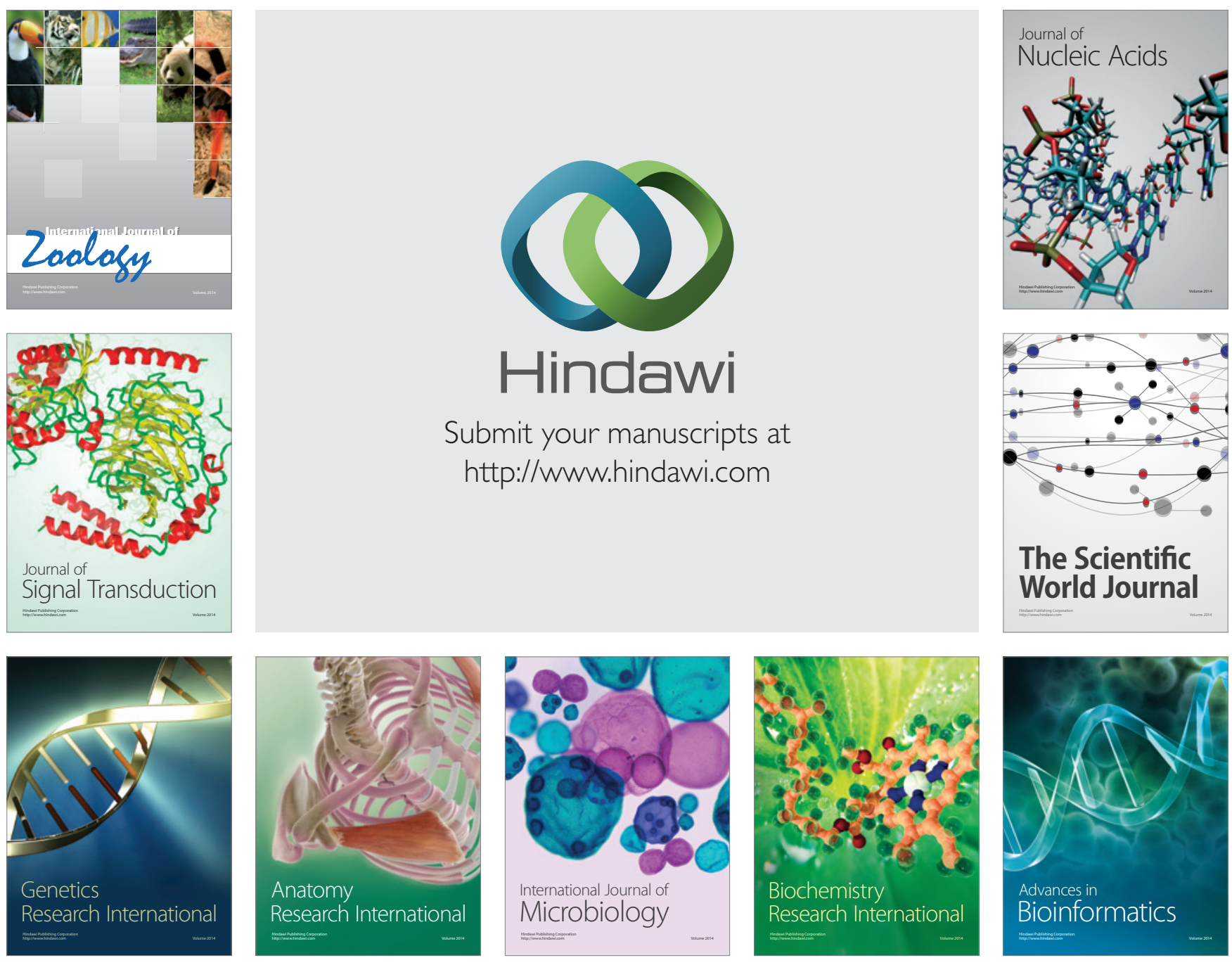

The Scientific World Journal
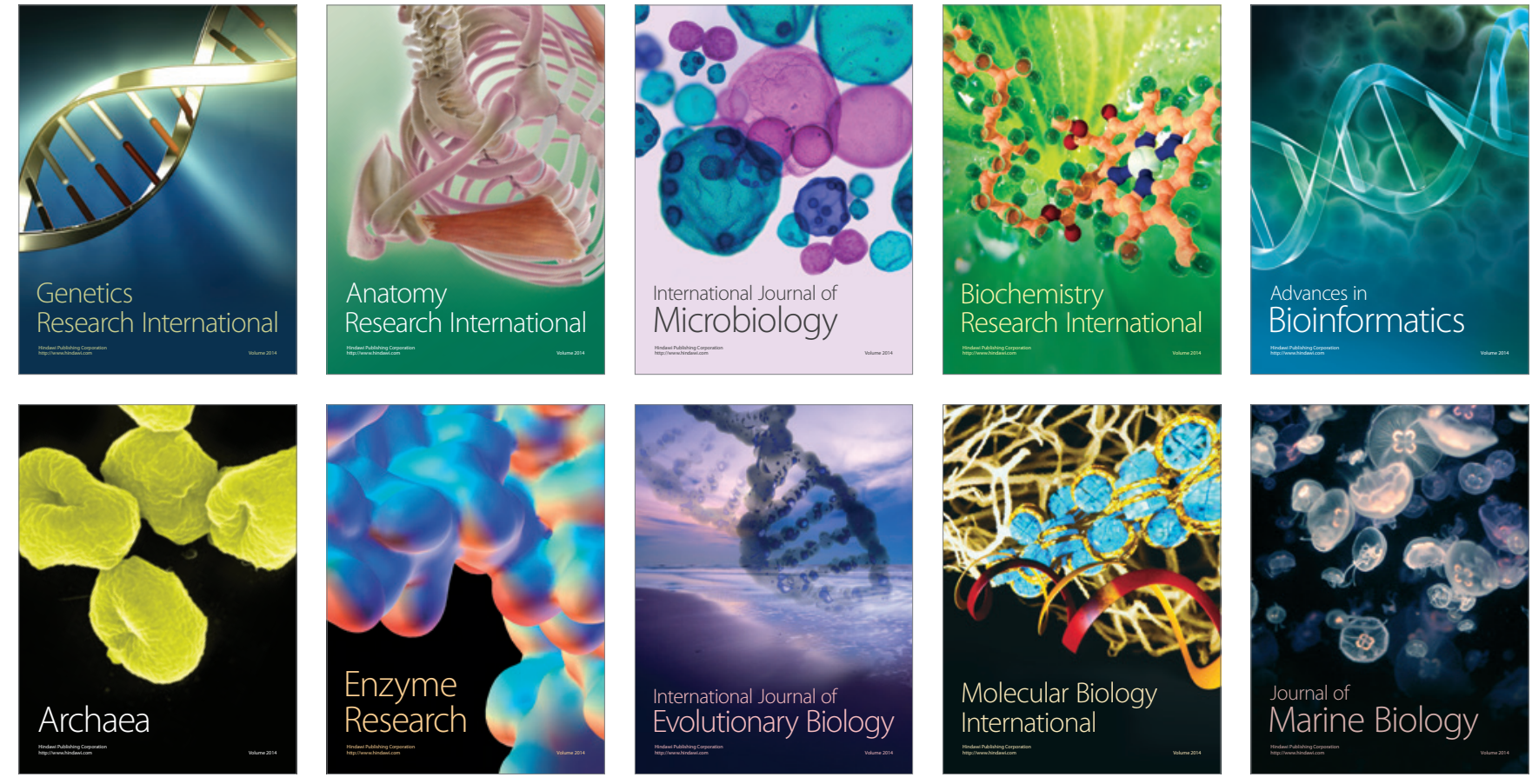